\title{
Mercury Biodecontamination from Milk by using L. acidophilus ATCC 4356
}

\author{
Ramona Massoud $^{1}$ (D) Kianoush Khosravi-Darani2* (D), Anousheh Sharifan ${ }^{3}$ (D), \\ Gholam Hassan Asadi ${ }^{3}$ (D) and Mohammad Rasoul Hadiani² \\ ${ }^{1}$ Department of Food Science and Technology, Iran Standard Organization Tehran, Iran. \\ ${ }^{2}$ Research Department of Food Technology, National Nutrition and Food Technology Research Institute, Faculty \\ of Nutrition Sciences and Food Technology, Shahid Beheshti University of Medical Sciences, Tehran, Iran. \\ ${ }^{3}$ Department of Food Science and Technology, Science and Research branch, Islamic Azad University, Tehran, Iran.
}

\begin{abstract}
Food and water contaminations with heavy metals have been increasing due to the environmental pollution. Decontamination of mercury as one of the most toxic heavy metals seems necessary. The aim of this study is to use $L$. acidophilus ATCC 4356 to reduce the mercury amount in milk. All possible process variables (including contact time, bacterial count, mercury concentration, temperature, contact time and shaking rate) were screening by Plackett Burman design for determination of main effects. Then main effects (contact time, as well as $\mathrm{Hg}$ and biomass concentration) were studied in 5 levels with response surface methodology to reach maximal bioremoval efficiency. The highest decontamination efficiency (72\%) was achieved in the presence of $80 \mu \mathrm{g} / \mathrm{L}$ of initial $\mathrm{Hg}$ concentration, $1 \times 10^{12} \mathrm{CFU}$ of L. acidophilus ATCC 4356 in the $4^{\text {th }}$ day. Finally, the capacity of this bacterium for Mercury bioremoval was determined at different $\mathrm{Hg}$ initial concentrations by using the isotherm models of Langmuir and Freundlich. The results showed the higher correlation coefficient in Langmuir model so, Mercury absorptions obey Langmuir isotherm model. This study indicated that in the case of milk contamination to $\mathrm{Hg}$, as reported in some countries, one of the solutions for metal decontamination could be the bioremoval by lactobacillus as natural valuable biosorbents as an environmental friendly technology.

Keywords: Lactobacillus acidophilus, Mercury, Biosorbent, Removal, Milk, Isotherm
\end{abstract}

*Correspondence: kiankh@yahoo.com

(Received: August 22, 2020; accepted: October 01, 2020)

Citation: Massoud R, Khosravi-Darani K, Sharifan A, Asadi GH, Hadiani MR. Mercury Biodecontamination from Milk by using L. acidophilus ATCC 4356. J Pure Appl Microbiol. 2020;14(4):2313-2321. doi: 10.22207/JPAM.14.4.10

(C) The Author(s) 2020. Open Access. This article is distributed under the terms of the Creative Commons Attribution 4.0 International License which permits unrestricted use, sharing, distribution, and reproduction in any medium, provided you give appropriate credit to the original author(s) and the source, provide a link to the Creative Commons license, and indicate if changes were made. 


\section{INTRODUCTION}

Heavy metals with the density of more than $5 \mathrm{~g} / \mathrm{cm}^{3}$ are the essential elements for human body such as Zinc, Iron and Copper whereas some others are toxic even in very low amounts (in the range of $\mu \mathrm{g} / \mathrm{L}$ ) like Lead, Cadmium, Arsenic and Mercury ${ }^{1}$. There is an unwanted increasing in pollution of heavy metals into the air, water and soil and therefore food ${ }^{2,3}$. The sources of Mercury pollution are classified as natural resources (weathering of rocks, volcanic activities and biological processes), and the industrial activities (electricity power stations, mining, production of chemical, pesticides, cement, chlorine, mirrors, medical equipment and wastewater ${ }^{4}$.

Milk is well-known all around the world for having vital effects on human health. The level of toxic metals is an important issue in quality and safety of milks. Mercury is one of the toxic metals widely spread in the environment, water and food ${ }^{6}$. Mercury is recognized as human carcinogenic metal and produces gastrointestinal and immunological disorders ${ }^{7}$. The scientific food safety agencies are responsible for human health. Codex standard for contaminants and toxins in food has allowed the maximum permissible limits for mercury concentration in milk as less than $0.05 \mu \mathrm{g} / \mathrm{L}^{8}$. There are some reports of mercury contamination in milk in some countries like China $0.08 \mu \mathrm{g} / \mathrm{L}^{9}$ and Iran, $0.07 \mu \mathrm{g} / \mathrm{L}^{10}$.

Chemical and biological techniques have been used to eliminate heavy metals from polluted solutions. Chemical process like using rezin $^{11}$, ion exchange ${ }^{12}$ and nanomaterials ${ }^{13}$ but they are not efficient for low concentrations of the heavy metals and also are expensive and not environmentally safe.

Biological methods include using biosorbents like plants and microorganisms e.g. yeasts, bacteria, algae and fungi for bioremoval of heavy metal from food and water ${ }^{14-16}$.

In the previous reports of this experimental team, we used Saccharomyces cerevisiae to remove heavy metals from water ${ }^{17}$ and milk ${ }^{18,19}$ but in this novel project the biosoption of mercury by L. acidophilus is evaluated as Lactic acid bacteria (LAB) are popular probiotics using all over the world.

The LAB have a desirable background of using in food processes in a safe manner as they are in the list of generally recognized as safe ${ }^{15}$. LABs have been reported to have the possibility in health applications and also bind the food contaminations like heavy metals and toxins even in low concentrations. Negative surface charge of LABs facilitates the binding to cations. So LAB would be a great microorganism for using in reduction heavy metals in water and foodstuffs ${ }^{20,21}$.

LABs have been reported to remove the heavy metals bioadsorption of $\mathrm{Cr}$ by a novel Bacillus sp. CRB-B122, $\mathrm{Hg}$ bioremoval by L. acidophilus ${ }^{6}$, biosorption of As by Bacillus ferrooxidans ${ }^{23}, \mathrm{Cd}$ bioremoval by Bacillus coagulans and $L$. plantarum ${ }^{24}, \mathrm{Hg}$ bioremoval by $B$. cereus ${ }^{25}$, Se uptake by $L$. acidophilus ${ }^{26}$ and As removal by $L$. acidophilus ${ }^{27}$. The gap of research in the previous reports, is the lack of an experimental design to evaluate all process variables for removal of heavy metal in the foodstuff and water ( $\mu \mathrm{g} / \mathrm{L}$ levels) instead of removal of heavy metal in wastewater (mg/L levels).

The aim of this study was to evaluate the capability of L. acidophilus ATCC 4356 for removing of mercury in milk in the range of $\mu \mathrm{g} / \mathrm{L}$. So, at first all possible process variables (including contact time, bacterial concentration, mercury concentration, temperature, contact time and shaking rate) were listed for a screening method of Plackett Burman design (PBD) and determination of main effects. Then, the main variables (contact time, as well as $\mathrm{Hg}$ and biomass concentration) have been studied in in 5 levels in response surface methodology (RSM) to reach the optimum condition for bioremoval efficiency. Finally, the capacity of $L$. acidophilus for Mercury bioremoval was determined at different $\mathrm{Hg}$ initial concentrations and also the biosorption isotherms were evaluate by using the two most famous isotherm models: Langmuir and Freundlich.

To our knowledge, there is no published study about the capability of L. acidophilus in biosorption of mercury in milk and this would be the first step of applying this valuable microorganism to remove the low levels $(\mu \mathrm{g} / \mathrm{L})$ of $\mathrm{Hg}$ concentration in milk successfully, therefore these results would open a new window in food decontamination by using this green technology for heavy metals removal in food industry. 


\section{MATERIALS AND METHODS \\ Reagents and chemicals}

The standard solution of $\mathrm{Hg}\left(\mathrm{NO}_{3}\right)_{2}(1000$

$\mathrm{mg} / \mathrm{L}$, Merck, Spain) and MRS agar, MRS broth and plate count agar were obtained from Liofilchem (Zona Industriale, Italy). The other chemicals were: nitric acid (Merck), phosphate-buffered saline (HyClone, Spain), $\mathrm{H}_{2} \mathrm{O}_{2}$ (Prolabo, Spain) and bovine serum albumin (Labclinic, Spain).

\section{Bacterial strain and preparation}

L. acidophilus ATCC 4356 as one of the most available and widely used probiotic was selected and prepared from Tak Gen Zist Company (Tehran, Iran). The bacteria were inoculated in MRS broth $(10 \mathrm{ml})$, then incubated at $37^{\circ} \mathrm{C}$ for $48 \mathrm{~h}$. The viability of $L$. acidophilus cells was evaluated by total plate counting and MRS agar and plate count agar used for L. acidophilus counting ${ }^{28}$.

\section{Sample preparation}

The milk samples were designed according to the following schematic diagram (Fig. 1). Then the analysis was carried out through storage period.

\section{Hg Analysis}

The inductively coupled plasma mass spectrometer (ICP-MS) 4500a (England) was applied in this study, with a cross flow rate nebulizer and a Peltier-cooled quartz spray chamber. It was tuned up by an aqueous multielement before each experiment. At first all the prepared samples were under digestion by using the microwave with segmented rotor MPR-600 (using pressure up to $35 \mathrm{bar}$; at $260^{\circ} \mathrm{C}$ ) ${ }^{29}$.

Plackett-Burman Design and selection of variables The bacterial concentration, inoculation temperature, contact time, Mercury concentration and shaking rate are the effective independent variables on Mercury bioremoval by L. acidophilus as mentioned in previous studies ${ }^{6,30}$. The variables were selected in this project by the help of literature reviews and pre-experience study (Table 1). Table 1 shows PBD for evaluation of 5 process variables in two levels.

The levels of Mercury concentration were selected by the aim of this project to study the potentiality of L. acidophilus to remove the low levels of Mercury $(\mu \mathrm{g} / \mathrm{L})$ in milk. Up to now there is no published information on this issue. For designed experiment of biosorption, the bacterial concentration $\left(1 \times 10^{11}\right.$ and $\left.1 \times 10^{12} \mathrm{CFU}\right)$ was added to sterile milk of $37^{\circ} \mathrm{C}$ in $250 \mathrm{~mL}$ Erlenmeyer flasks with the rest time of 20 minutes then Mercury (40 and $80 \mu \mathrm{g} / \mathrm{L}$ ) added to the flasks. After that the flasks were put at on the shaker. At the contact time $\left(1^{\text {st }}\right.$ or $4^{\text {th }}$ day $)$, bacteria cells were centrifuged at $8000 \times \mathrm{g}$ for $20 \mathrm{~min}$. Then the supernatant was analyzed for residual Mercury concentration

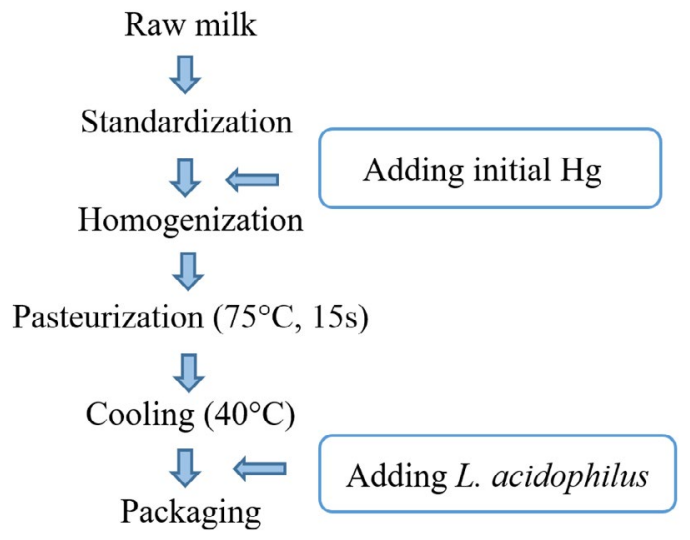

Fig. 1. Schematic diagram of milk samples production

Table 1. Plackett-Burman for evaluation of impact of the variable on Mercury biosorption by L. acidophilus

\begin{tabular}{lccccc}
\hline Run & $\begin{array}{c}\text { Bacterial } \\
\text { concen. } \\
(\mathrm{CFU})\end{array}$ & $\begin{array}{c}\text { Inoculation } \\
\text { Temp. }\left({ }^{\circ} \mathrm{C}\right)\end{array}$ & $\begin{array}{c}\text { Contact } \\
\text { time } \\
\text { (day) }\end{array}$ & $\begin{array}{c}\text { Mercury } \\
\text { concen. } \\
(\mu \mathrm{g} / \mathrm{L})\end{array}$ & $\begin{array}{c}\text { Shaking } \\
\text { rate } \\
(\mathrm{rpm})\end{array}$ \\
\hline 1 & $1 \times 10^{11}$ & 40 & 4 & 100 & 0 \\
2 & $1 \times 10^{12}$ & 4 & 1 & 100 & 50 \\
3 & $1 \times 10^{11}$ & 4 & 4 & 100 & 50 \\
4 & $1 \times 10^{12}$ & 40 & 1 & 100 & 0 \\
5 & $1 \times 10^{11}$ & 4 & 1 & 40 & 0 \\
6 & $1 \times 10^{12}$ & 4 & 4 & 40 & 0 \\
7 & $1 \times 10^{11}$ & 40 & 1 & 40 & 50 \\
8 & $1 \times 10^{12}$ & 40 & 4 & 40 & 50 \\
\hline Journal of Pure and Applied Microbiology & & 2315 &
\end{tabular}


by ICP- MS. All these experiments were carried out in triplicates. The ability of $L$. acidophilus to absorb Mercury was estimated by the following equation $^{31}$ :

$\%$ Removal $=100 \times\left[\left(C_{0}-C 1\right) / C_{0}\right]$

Where $C_{0}$ is the initial and $C_{1}$ is residual Mercury concentration.

The data were analyzed using the Minitab (version 14) statistical software. According to the variance analysis, the 3 main variables were: Mercury concentration, L. acidophilus concentration and the contact time.

Response surface methodology (RSM)

RSM is the usage of statistical and mathematical techniques together for analyzing the independent variables on the responses. RSM is a helpful application in optimizing and improving the precess design. This method is more practical by applying interactive computer programs between the variables based on experimenter's prior knowledge. After all it represents the parameters effects on the process ${ }^{32}$.

The Plackett-Burman results showed that 3 variables; L. acidophilus concentration, Mercury concentration and contact time, having significant effect on mercury bioremoval. RSM was designed for a completed determination of optimum variable levels for Mercury bioremoval and also elimination the tests number. In our project, CCD was used to find the optimal bioremoval conditions with the experimental factors levels displayed in the Table 2 .

The other factors were kept constant as the following: the inoculation temperature at $25^{\circ} \mathrm{C}$ and the shaking rate at $50 \mathrm{rpm}$. For data analysis the Design- Expert 7.1.5 (Stat-Ease Inc., USA) software was used. The bioremoval runs were performed by the 5 levels of each variable (Table 2 ) and then the tests obtained by CCD.

\section{Evaluation of the capacity of binding metal}

The maximum capacity of binding Mercury would be predicted with the different isotherm models like Langmuir and Freundlich. The absorption models used for explaining absorption system of the bacterial cells in biosorption of metals at the contact time ${ }^{33,34}$.

\section{Statistical Analysis}

The results of statistical analysis were done by MINITAB statistical software (version 14) and the response surface plots were prepared. The statistical data were provided by analysis of variance. All data are represented as the mean value \pm standard deviation $(M \pm S D)$ of independent experiments in mentioned days. $P$-values below 0.05 were statistically significant.

\section{RESULTS AND DISCUSSION}

RSM for optimization of Mercury bioremoval

The analysis of variance showed the effect of the variables designed by Plackett-Burman Design. Using RSM after analysis of variance showed that the Mercury bioremoval level is the result of the 3 variables shown in Table 3. The P-values $<0.05$ showed that the model terms are significant. In this study Mercury concentration, contact time and biomass dosage are significant model terms.

Study the influencing factors on the effect of $L$. acidophilus on Mercury bioremoval

The factors influencing on biosorption of mercury by $L$. acidophilus in milk were analyzed and described below:

Effect of $L$. acidophilus concentration and contact time on removal efficiency

In this study, the experiments were done for evaluating the ability of $L$. acidophilus concentration in the range of $10^{10}$ to $10^{13} \mathrm{CFU}$ on Mercury biosorption efficiency during the

Table 2. Main variables and levels for Mercury biosorption by L. acidophilus by central composite design

\begin{tabular}{lcccccc}
\hline \multicolumn{5}{c}{ Range and level } \\
\hline $\begin{array}{l}\text { Independent process } \\
\text { variable }\end{array}$ & $-\alpha(-1.68)$ & -1 & 0 & +1 & $+\alpha(+1.68)$ & \\
$\begin{array}{l}\text { L. acidophilus } \\
\text { concentration (CFU) }\end{array}$ & $1 \times 10^{10}$ & $10 \times 10^{11}$ & $1 \times 10^{12}$ & $10 \times 10^{13}$ & $10 \times 10^{14}$ & \\
$\begin{array}{l}\text { Initial Hg } \\
\text { concentration) } \mu \mathrm{g} / \mathrm{L})\end{array}$ & 40 & 50 & 70 & 90 & 100 & \\
$\begin{array}{l}\text { Contact time (day) } \\
\text { Journal of Pure and Applied Microbiology }\end{array}$ & 0 & 1 & 2 & 3 & 4 & www.microbiologyjournal.org
\end{tabular}


contact times of 1 to 4 days. Fig. 1 . shows the data collected from Mercury biosorption by $L$. acidophilus at different contact times. As it shows the maximum binding rate of $\mathrm{Hg}$ occurred in the $4^{\text {th }}$ day. The removal efficiency of this heavy metal first enhanced with rising the bacterial concentration and contact time and reached to the maximum level and the further increase of bacterial concentration, caused a light decrease in removal level.

In general, heavy metals biosorption is a complicated mechanism. There are 3 theories in metal binding; the ion exchange with cell walls' teichoic acid and peptidoglycan, the precipitation and the ligands formation ${ }^{20}$.

Lactic acid bacteria are gram positive and their cell walls contain a thick layer of teichoic acid, peptidoglycan and exopolysaccharides. The surface functional groups; carboxyl, hydroxyl, phosphate make the negative charges in $L$. acidophilus. So, the bacteria would be able to absorb the cationic ions of heavy metals ${ }^{20,35}$.
The light decrease trend in removal process could be explain as a result of the bacteria partial aggregation at higher concentrations that causes the decrease in free sites in surface protein and exopolysaccharides and finally decreased biosorption ${ }^{35,36}$. In this study, the highest Mercury removal efficiency was $72 \%$ in biomass of $1 \times 10^{12} \mathrm{CFU}$ in the 3 rd day. Similar studies reported the same results for increasing biosorption during exposure time by Halttunen ${ }^{35}$ for Lactic acid bacteria, Rayes ${ }^{37}$ for L. rhamnosus and $L$. fermentum. It has been reported that metal binding is a process carried out on the bacteria cell surface efficiently with no energy consumption ${ }^{35}$.

As shown in Fig. 2. Mercury bioremoval enhanced by increasing the contact time from 1st to 4th day in addition to rising the bacteria concentration. The optimum level of $L$. acidophilus was $1 \times 10^{12} \mathrm{CFU}$. It is sensible that by increasing the contact time, more Mercury ions would be connected to bacteria surface receptors and the

Table 3. Analysis of variance of parameters studied for Mercury biosorption by L. acidophilus

\begin{tabular}{lcccccc}
\hline Source & $\begin{array}{c}\text { Sum of } \\
\text { Squares }\end{array}$ & df & $\begin{array}{c}\text { Mean } \\
\text { Squares }\end{array}$ & F-value & p-value \\
\hline Shaking rate & 0.211 & 1 & 0.211 & 2.88 & 0.4125 \\
Mercury concentration & 9.87 & 1 & 9.87 & 94.02 & 0.0542 \\
L. acidophilus concentration & 9.38 & 1 & 9.38 & 78.35 & 0.0712 \\
Contact time \\
Inoculation temperature
\end{tabular}

Fig. 2. Contour plot showing interactive effect of $L$. acidophilus concentration dosage and contact time on the Mercury removal 
Table 4. Langmuir and Freundlich isotherm parameters of $\mathrm{Hg}$ in various initial concentrations

\begin{tabular}{lcccccc}
\hline \multirow{2}{*}{$\begin{array}{l}\text { Hg initial } \\
(\mu \mathrm{g} / \mathrm{L})\end{array}$} & \multicolumn{2}{c}{ Langmuir model } & & \multicolumn{2}{l}{ Freundlich model } \\
\cline { 7 - 8 } \cline { 7 - 8 } & Ce & Qe & Ce/Qe & & Ln Qe & Ln Ce \\
\hline 20 & 10.5 & 9.4 & 1.128 & & 2.241 & 2.361 \\
40 & 18 & 22 & 0.818 & & 3.091 & 2.890 \\
60 & 22 & 38 & 0.563 & & 3.648 & 3.073 \\
80 & 24 & 56 & 0.429 & & 4.025 & 3.178 \\
100 & 25 & 75 & 0.333 & & 4.317 & 3.219 \\
\hline
\end{tabular}

bioremoval process would be more efficient by time.

Effect of $L$. acidophilus concentration and Mercury concentration on removal efficiency

The effect of $L$. acidophilus concentration and initial Mercury concentration on the biosorption was investigated in the range of $10^{10}$ to $10^{13} \mathrm{CFU}$ and $40-100 \mu \mathrm{g} / \mathrm{L}$, respectively (Fig. 3.). The results revealed that by increasing the Mercury concentration, the adsorption increased. As shown in Fig. 3. Increasing $L$. acidophilus concentration up to $1 \times 10^{12} \mathrm{CFU}$, make the removal efficiency enhancing. The maximum Mercury removal efficiency (72\%) was observed at the initial Mercury concentration of $80 \mu \mathrm{g} / \mathrm{L}$ and the biomass concentration of $1 \times 10^{12}$ CFU. L. acidophilus shows a high affiliation for biosorption of heavy metals ${ }^{35,38}$. Heavy metals binding is a surface process as the presence of anionic functional groups and it also depends on the capacity of the bacteria strains and the metal electronegativity ${ }^{20}$. It is reported that metal absorption in bacteria cells could be explained by the interactions between the heavy metals and the negative charge of bacteria surface. Gram positive bacteria like $L$. acidophilus have some polymers like lipoteichoic acid in their cell wall that can be responsible for such interactions ${ }^{20,39}$.

It is observed that by rising the metal concentration, the absorption to the bacteria receptors would also increase, which results in the higher bioremoval level ${ }^{38,40}$.

According to our findings Mercury biosorption efficiency increased by increasing the Mercury concentration in the range of 40 to 100 $\mu \mathrm{g} / \mathrm{L}$. The important factors as shown in Fig. 3, are Mercury concentration and the $L$. acidophilus concentration for Mercury bioremoval and their optimum levels are $80 \mu \mathrm{g} / \mathrm{L}$ and $1 \times 10^{12} \mathrm{CFU}$ for the maximum level (72\%) of the biosorption. The same results were reported by Dobrowolski ${ }^{40}$, Allam $^{41}$, Akhmetsadykova ${ }^{42}$ and Halttunen ${ }^{35}$ as the absortion would improve by increasing the bacterial concentration. Also by increasing the metal concentration, the biosorption would enhance as mentioned in some studies by Massoud ${ }^{18}$ Halttunen $^{35}$, Shameer ${ }^{36}$, Kinosita ${ }^{38}$.

\section{Isotherm model studies}

The capacity of $L$. acidophilus concentration $\left(10^{12} \mathrm{CFU} / \mathrm{mL}\right)$ for Mercury bioremoval was determined at different mercury initial concentrations $(20,40,60,80$ and 100 $\mu \mathrm{g} / \mathrm{L})$. The biosorption isotherms are detemined

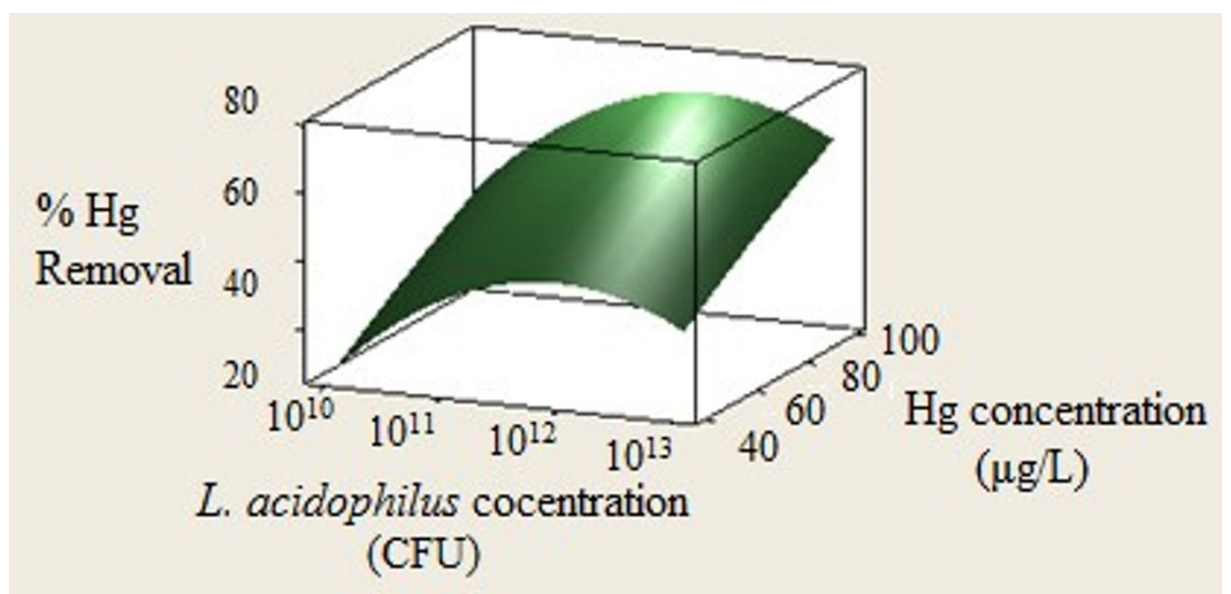

Fig. 3. Contour plot showing interactive effect of $L$. acidophilus concentration and $\mathrm{Hg}$ concentration on the Mercury removal

Journal of Pure and Applied Microbiology

2318

www.microbiologyjournal.org 

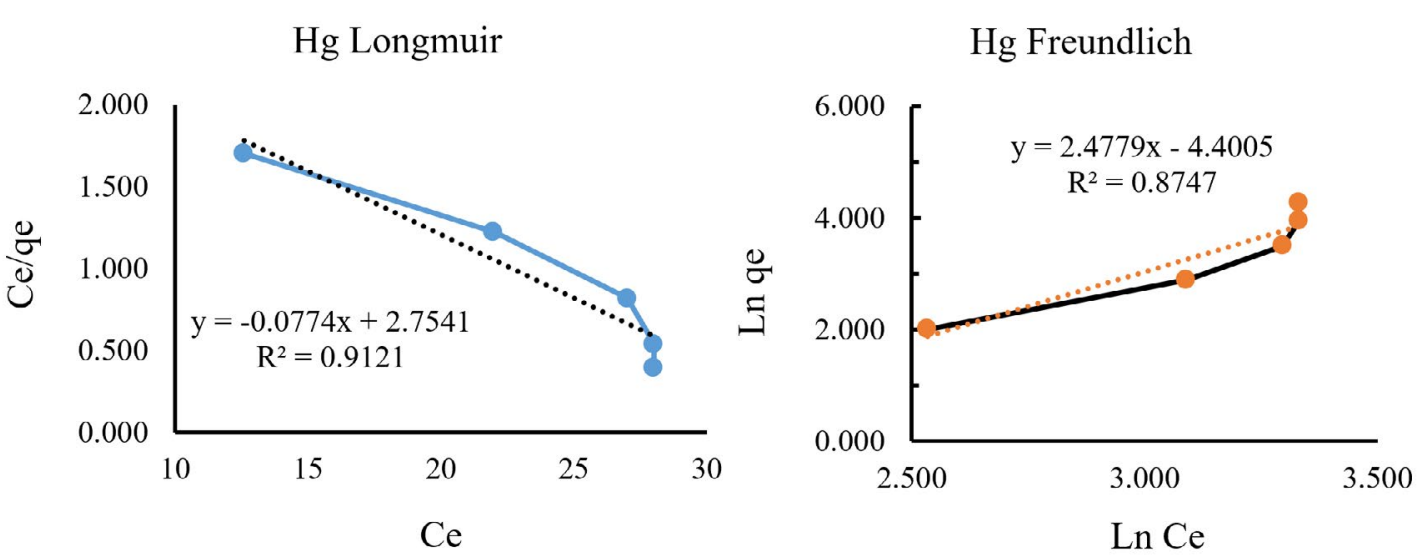

Fig. 4. Langmuir absorption isotherm curve (A), Freundlich absorption isotherm curve (B)

by using the isotherm models such as Langmuir and Freundlich. The regression coefficient $\left(R^{2}\right)$ show the best isotherm describing the Mercury biosorption by $L$. acidophilus. All the experiments were performed in three replications.

The Langmuir model is the most common model used in scientific studies. The Langmuir equation is correct for monolayer absorption using the following equation ${ }^{33}$ :

$$
\mathrm{C}_{\mathrm{e}} / \mathrm{Q}_{\mathrm{e}}=1 /\left(\mathrm{K}_{*} \mathrm{Q}_{\max }\right)+\mathrm{C}_{\mathrm{e}} / \mathrm{Q}_{\max }
$$

Where $Q_{e}(\mu \mathrm{g} / \mathrm{L})$ is the amount of $\mathrm{Hg}$ in absorbing equilibrium, $C_{e}(\mu \mathrm{g} / \mathrm{L})$ is the equilibrium concentration of $\mathrm{Hg}$ in milk, $Q_{\max }(\mu \mathrm{g} / \mathrm{L})$ is the maximum $\mathrm{Hg}$ absorption in high $\mathrm{C}_{\mathrm{e}}$ level; and $\mathrm{K}_{\mathrm{L}}$ $(\mathrm{L} / \mu \mathrm{g})$ is the Langmuir constant. The $\mathrm{C}_{\mathrm{e}} / \mathrm{Q}_{\mathrm{e}}$ versus $\mathrm{C}_{\mathrm{e}}$ indicate a straight line of slope $1 / \mathrm{Q}_{\max }$ and also intercept of $1 / \mathrm{K}_{\mathrm{L}} \mathrm{Q}_{\max }$.

The Freundlich equation is as the following equation ${ }^{34}$ :

$$
\operatorname{Ln} Q_{e}=\operatorname{Ln} K_{f}+1 / n \operatorname{Ln} C_{e}
$$

Where $K_{f}$ and $n$ is the Freundlich constants. The parameters $K_{F}$ and $n$ is defined from the linear plot of $\ln Q_{e}$ versus $\ln C_{e}$. Freundlich equation varies with the materials heterogeneity. The Langmuir and Freundlich models' parameters are given in Table 4.

As shown in Fig. 4. A and B, the biosorption enhanced by increasing the initial Mercury concentration, because more metal concentration supplied more possible ions of Mercury ions to bind with absorbents' functional groups ${ }^{6,43}$. By comparing the both $\mathrm{R}^{2}$ values in Langmuir and Freundlich models, it was inferred that Langmuir isotherm model showed better fit than Freundlich model, which also confirm that Freundlich equation is correct for monolayer absorption on surface binding. The higher correlation coefficient in Langmuir model indicates the Mercury absorptions obey Langmuir isotherm model.

\section{CONCLUSION}

The mercury presence in water and food is a public health problem. The European Rapid Alert System for Food and Feed $(2018)^{44}$ have reported that heavy metals are the contaminants that attracts the high notifications in water and food and Lead, Cadmium and Mercury are the ones that make the most problems for people. Among all the food and drinks, milk is the most sensible one that should be safe enough to be consumed. In this project, RSM was used to evaluate the optimal condition for Mercury bioremoval by of $L$. acidophilus. Our findings showed the highest level of Mercury bioremoval of $72 \%$ in the concentration of $1 \times 10^{12} \mathrm{CFU}$, the Mercury concentration of $80 \mu \mathrm{g} / \mathrm{L}$ and in the 4 th day. The biosorption increased by increasing the metal and bacteria concentration as well as the contact time. This study represented the ability of $L$. acidophilus for Mercury removal in very low concentration levels $(\mu \mathrm{g} / \mathrm{L})$ from milk. Also, these findings open the doors of investigating the capacity of Mercury binding by LABs in milk. Further studies are suggested for other LAB strains in milk and foodstuffs to reduce the toxic effects of the heavy metals. 


\section{ACKNOWLEDGMENTS}

We would like to thank the National Nutrition and Food Technology Research Institute (NNFTRI) of Iran for supporting this project. The authors would like to thank Dr. A. Zoghi and for her kind assistance.

\section{CONFLICT OF INTEREST}

The authors declare that there is no conflict of interest.

\section{AUTHORS' CONTRIBUTION}

All authors have made substantial contribution to the work and approved it for publication.

\section{FUNDING}

This work was supported by Shahid Beheshti University of Medical Sciences (Grant number 22408).

\section{ETHICS STATEMENT}

This article does not contain any studies with human participants or animals performed by any of the authors.

\section{DATA AVAILABILITY}

Not applicable.

\section{REFERENCES}

1. Arif TJ, Mudsser A, Kehkashan S, et al. Heavy Metals and Human Health, Mechanistic Insight into Toxicity and Counter Defense System of Antioxidants. Int J Mol Sci. 2015;16(12):592-630. doi: 10.3390/ijms161226183

2. Jaiswal G, Singh R, Porwal S. Bioremediation of Mercury through Encapsulation of the Clone Carrying meroperon. J Pure Appl Microbiol. 2019;13(1):553560. doi: 10.22207/JPAM.13.1.62

3. Wang Y, Dang F, Zhong H. Effects of sulfate and selenite on mercury methylation in a mercury-contaminated rice paddy soil under anoxic conditions. Environ Sci Pollut Res. 2016;23:4602-4608. doi: 10.1007/s11356015-5696-8

4. McConnell JR, Edwards R. Coal burning leaves toxic heavy metal legacy in the Arctic. Proc Natl Acad Sci. 2008; 105(34):12140-12144.doi: 10.1073/ pnas.0803564105

5. Lucey JA. Raw Milk Consumption, Risks and Benefits. Nutr Today. 2015;50(4):189-193. doi: 10.1097/ NT.0000000000000108

6. Jadan-Piedra C, Alcantara C, Monedero V, Zuniga M, Velez D, Devesa V. Effect of lactic acid bacteria on mercury toxicokinetics. Food Chem Toxicol. 2009;128:147-153. doi: 10.1016/j.fct.2019.04.001
7. Bjorklunda G, Dadarb M, Mutterc J, Aaseth J. The toxicology of mercury, Current research and emerging trends. J Environ Res. 2017;159: 545-554. doi: 10.1016/j.envres.2017.08.051

8. Codex stan 193. Codex General Standard for Contaminants and Toxins in Food and Feed. 2009.

9. Wang MQ, Wang ZT, Bao DY, Ran Chin L. Food contamination monitoring and analysis in 2000 in China. J Food Hyg. 2002;20:185-200.

10. Najarnezhad V, Akbarabadi M. Heavy metals in raw cow and ewe milk from north-east Iran. Food Add Contamin. 2013;3:158-162. doi: 10.1080/19393210.2013.777799

11. Naushad M, Vasudevan S, Sharma G, Kumar A, ALOthman ZA. Adsorption kinetics, isotherms, and thermodynamic studies for $\mathrm{Hg}^{2+}$ adsorption from aqueous medium using alizarin red-S-loaded amberlite IRA-400 resin. Desalin Water Treat. 2016;57(39): 18551-18559. doi: 10.1080/19443994.2015.1090914

12. Naushad M., ALOthman ZA, Awual MR. Adsorption kinetics, isotherms, and thermodynamic studies for the adsorption of $\mathrm{Pb}^{2+}$ and $\mathrm{Hg}^{2+}$ metal ions from aqueous medium using $\mathrm{Ti}(\mathrm{IV})$ iodovanadate cation exchanger. Ionics, 2015;21(8):2237-2245. doi: 10.1007/s11581015-1401-7

13. Awual R, Hasan M, Eldesokyc G, Khaleque A, Rahman MM, Naushad M. Facile mercury detection and removal from aqueous media involving ligand impregnated conjugate nanomaterials. Chem Engine J. 2016;290:243-251. doi: 10.1016/j.cej.2016.01.038

14. Massoud R, Hadiani MR, Khosravi Darani K. Bioremediation of heavy metals in food industry Application of Saccharomyces cerevisiae. Electron J Biotechnol. 2019a;37:56-6. doi: 10.1016/j. ejbt.2018.11.003

15. Chen W, Narbad A. Lactic Acid Bacteria in Foodborne Hazards Reduction The use of lactic acid bacteria to reduce mercury bioaccessibility. Springer Nature, Singapore. 2018. doi: 10.1007/978-981-13-1559-6

16. Eman Abdullah MA, Mohsen AS, Tahany MA, AbdelRahman AM. Bioremediation of Waste Water from Cadmium Pollution using Silicon Dioxide Nanoparticles and Fungal Biomasses. J Pure Appl Microbiol. 2019;13(3):1561-1570. doi: 10.22207/JPAM.13.3.29

17. Hadiani MR, Khosravi-Darani K, Rahimifard N, Younesi H. Assessment of Mercury biosorption by Saccharomyces cerevisiae, Response surface methodology for optimization of low $\mathrm{Hg}$ (II) concentrations. J Environ Chem Engin. 2018;6(4):4980-4987. doi: 10.1016/j.jece.2018.07.034

18. Massoud R, Khosravi-Darani K, Sharifan A, Asadi $\mathrm{GH}$. Lead bioremoval from milk by Saccharomyces cerevisiae. Biocatal Agric Biotechnol. 2019b;22:11-20. doi: 10.1016/j.bcab.2019.101437

19. Massoud R, Khosravi-Darani K, Sharifan A, Asadi, GH. Cadmium Bioremoval by Saccharomyces cerevisiae In Milk. J Med Microbiol Infect Dis. 2020;12:22-30. doi: 10.29252/JoMMID.8.1.29

20. Zoghi A, Khosravi-Darani K, Sohrabvandi S. Surface binding of toxins and heavy metals by probiotics. Mini Rev Med Chem. 2014;14:84-98. doi: 10.2174/138955 7513666131211105554

21. Mrvcic J, Stanzer D, Solic E, Stehlik-Tomas V. Interaction 
of lactic acid bacteria with metal ions: opportunities for improving food safety and quality. World J Microbiol Biotechnol. 2012;28(9):2771-2782. doi: 10.1007/ s11274-012-1094-2

22. Tan $\mathrm{H}$, Wang $\mathrm{C}$, Zeng $\mathrm{G}$, Luo $\mathrm{Y}, \mathrm{Li} \mathrm{H}, \mathrm{Xu} \mathrm{H}$. Bioreduction and biosorption of $\mathrm{Cr}(\mathrm{VI})$ by a novel Bacillus sp. CRB-B1 strain. J Hazard Mat. 2020;386:12-18. doi: 10.1016/j. jhazmat.2019.121628

23. Shenghui $X$, Ruixiang $X$, Zhongren $N$, Peng $C$. Bioadsorption of arsenic from aqueous solution by the extremophilic bacterium Acidithiobacillus ferrooxidans DLC-5. Biocat Biotrans. 2018;37(1):35-43. doi: 10.1080/10242422.2018.1447566

24. Majlesi M, Shekarforoush SS, Ghaisari HR, Nazifi $\mathrm{S}$, Sajedianfard J. Effect of Bacillus coagulans and Lactobacillus plantarum as probiotic on decreased absorption of cadmium in rat. J Food Hygin. 2017;6(22):25-33.

25. Hirak R, Dash S, Das S. Corrigendum to "Bioremediation of inorganic mercury through volatilization and biosorption by transgenic Bacillus cereus BW-03. Int Biodet Biodeg. 2015;103:179-185. doi: 10.1016/j. ibiod.2015.04.022

26. Beladi M, Akhavan Sepahi A, Mehrabian S, Esmaeili A, Sharifnia F. Antibacterial Activities of Selenium and Selenium Nano-particles from Lactobacillus acidophilus on Nosocomial Strains Resistant to Antibiotics. J Pure Appl Microbiol. 2015;9(4):28432851.

27. Singh AL, Sarma PN. Removal of arsenic from water using Lactobacillus acidophilus. Biorem J. 2010;14(2):92-97. doi: 10.1080/10889861003767050

28. Vinderola CG, Reinheimer JA. Enumeration of Lactobacillus casei in the presence of Lactobacillus acidophilus Bifidobacteria and lactic starter bacteria in fermented dairy products. Int Dairy J. 2000;10(4):271275. doi: 10.1016/S0958-6946(00)00045-5

29. Khan $N$, Jeong $S$, Hwang $M$, et al. Analysis of minor and trace elements in milk and yogurts by inductively coupled plasma-mass sperometry (ICPMS). Food Chem. 2014;147:220-224. doi: 10.1016/j. foodchem.2013.09.147

30. Pakdel M, Soleimanian-Zad S, Akbari-Alavijeh S. Screening of Lactic acid bacteria to detect potent biosorbents of lead and cadmium. Food Control. 2019;100:144-150. doi: 10.1016/j. foodcont.2018.12.044

31. Goksungur Y, Uren S, Guvenc U. Biosorption of cadmium and lead ions by ethanol treated waste baker's yeast biomass. Biores Technol. 2015;96:103109.
32. Bas D, Boyac IH. Modeling and optimization usability of response surface methodology. J Food Eng. 2007;78(3):836-845. doi: 10.1016/j. jfoodeng.2005.11.024

33. Langmuir I. The adsorption of gases on plane surfaces of glass mica and platinum. J Am Chem Soc. 1918;40(9):1361-1403. doi: 10.1021/ja02242a004

34. Freundlich HM. The adsorption in solutions. Chem. 1906;57:385-470.

35. Halttunen T, Salminen S, Jussi M, Raija T, Kalle L. Reversible surface binding of cadmium and lead by lactic acid and bifidobacteria. Int J Food Microbiol. 2008;125(2):170-175. doi: 10.1016/j. ijfoodmicro.2008.03.041

36. Shameer S. Biosorption of lead copper and cadmium using the extracellular polysaccharides (EPS) of Bacillus sp. from solar salterns. 3 Biotech. 2016;6(2):194 - 200. doi: 10.1007/s13205-016-0498-3

37. Rayes AAH. Field studies on the removal of lead cadmium and copper by the use of probiotic lactic acid bacteria from the water for culturing marine tilapia T. spilurus. New York Sci J. 2012;5(11):120-125.

38. Kinoshita $\mathrm{H}$, Yui S, Fumika $\mathrm{O}$, et al. Biosorption of heavy metals by lactic acid bacteria and identification of mercury binding protein. Res in Microbiol. 2013;164(7):701-709. doi: 10.1016/j. resmic.2013.04.004

39. Alcantara C, Jadan-Piedra C, Velez D, Devesa V, Zuniga $\mathrm{M}$, Monedero V. Characterization of the binding capacity of mercurial species in Lactobacillus strains. J Sci Food Agricul. 2017;97(15):5107-5113. doi: $10.1002 /$ jsfa. 8388

40. Dobrowolski R, Szczes A, Czemierska M, JaroszWikolazka A. Studies of cadmium (II) lead (II) nickel(II) cobalt(II) and chromium(VI) sorption on extracellular polymeric substances produced by Rhodococcus opacus and Rhodococcus rhodochrous. Biores Technol. 2017;225:113-120. doi: 10.1016/j. biortech.2016.11.040

41. Allam NG, Ali EM, Samya S, Abd-Elrahman E. The role of probiotic bacteria in removal of heavy metals. Egyp. J Environ Res. 2015;3:1-11.

42. Akhmetsadykova S, Konuspayeva G, Loiseau G, et al. Protection against lead contamination by strains of lactic acid bacteria from fermented camel milk. J. Food Agricul. 2013;25(4):274-282.

43. Mironyuk I, Tatarchuk T, Naushad M, Vasylyeva H, Mykytyn I. Highly efficient adsorption of strontium ions by carbonated mesoporous $\mathrm{TiO}_{2}$. J Molecul Liquids. 2019;285:742-753. doi: 10.1016/j.molliq.2019.04.111

44. European Rapid Alert System for Food and Feed. European Commission annual report. 2018. 